\title{
The Contribution of Technological Approaches in Reducing Maternal Mortality: An Integrative Review
}

\author{
Najma Naz ${ }^{1,2 *}$, Grace T.M. Dal Sasso ${ }^{2}$, Sabiha Khanum³ ${ }^{3}$ Maria de Lourdes de Souza ${ }^{3}$, \\ Vera Radünz ${ }^{4}$ \\ ${ }^{1}$ Saidu Group of Teaching Hospital, Saidu Sharif, Pakistan \\ ${ }^{2}$ Post Graduate Program in Nursing (GIATE/UFSC), Federal University of Santa Catarina, Florianópolis, Brazil \\ ${ }^{3}$ Post Graduate Program in Nursing (PEN/UFSC), Repensul Institute, Federal University of Santa Catarina, \\ Florianópolis, Brazil \\ ${ }^{4}$ Post Graduate Program in Nursing (PEN/UFSC), Federal University of Santa Catarina, Florianópolis, Brazil \\ Email: *najma.sayyed@live.com
}

Received 14 February 2016; accepted 6 March 2016; published 9 March 2016

Copyright (C) 2016 by authors and Scientific Research Publishing Inc.

This work is licensed under the Creative Commons Attribution International License (CC BY). http://creativecommons.org/licenses/by/4.0/

(c) (i) Open Access

\section{Abstract}

Aim: To analyze the role of available health technologies and techniques in reducing the number of women dying during pregnancy and childbirth. Background: Health condition of women during pregnancy and childbirth is very sensitive. During this period, proper and timely care plays an important role in reducing maternal mortality. Design: Whitte more and Knafl's framework for integrative reviews was followed in the review. PUBMED/MEDLINE, CINHAL and COCHRANE were searched for published studies between 2008 and 2015. Studies included were systematic reviews, randomized control trials, prospective cohort study, literature review and descriptive studies. Methods: 28 articles were selected to be included in the review. An integrative review approach was followed to analyze data and draw conclusions. Screening of titles and abstracts along with data extraction was completed by two authors independently. Study quality is not reported because of the methodological difficulties. Data synthesis consists of writing descriptive summaries and thematic analysis of the key findings in the included articles. Results: The included studies were based on health technologies and techniques including different devices and tools, medication and drugs, massage techniques, immersion in water, intervention radiology, simulations and training for the health professional. Conclusion: There are numerous health technologies and techniques which are relatively simple to develop, effective to use and safe to apply with no adverse effects. These include simulations and training programs, educational and awareness programs, decision support tools and information systems. Besides these, there are technologies and techniques which show promising results with no or very little adverse effects. These include Ac-

\footnotetext{
${ }^{*}$ Corresponding author.
}

How to cite this paper: Naz, N., Dal Sasso, G.T.M., Khanum, S., Souza, M.L. and Radünz, V. (2016) The Contribution of Technological Approaches in Reducing Maternal Mortality: An Integrative Review. Open Journal of Nursing, 6, $133-147$. http://dx.doi.org/10.4236/ojn.2016.63015 
tive management of the third stage of labour, use of magnesium sulphate, uterine balloon tamponade, wearable cardiac defibrillator and non-pneumatic anti-shock garment. The government, hospitals and care providers should make policies to develop and implement such type of technologies and techniques.

\title{
Keywords
}

\author{
Health Technologies, Maternal Mortality, Pregnancy, Childbirth, Maternal Health
}

\section{Introduction}

Health condition of women during pregnancy and childbirth is referred to as maternal health. All health care aspects including preconception care, prenatal care and postnatal care, during this period, play a very important role in reducing maternal mortality.

Preconception care is the care provided to women before they get pregnant. It includes awareness, education and knowing about any possible problems and risks that might affect women and their babies later when they get pregnant. Prenatal care also known as antenatal care is the health care provided to women during pregnancy (when they get pregnant till the time they deliver). It includes medical checkups and prenatal testing. The goal is to detect any potential pregnancy complications early and keep women and her baby healthy. The postnatal period starts immediately after the birth of a child and extends for about six to eight weeks. Postnatal care is the care provided to women during the postnatal period. It includes recovery of a mother from childbirth, health and nutrition concerns of newborn, breastfeeding, community and partner support and family planning [1].

In developed countries, the health outcomes of pregnancy-related complications have remarkably improved [2]. This improvement in maternal health is realized due to the use of advanced technologies and techniques such as the use of simulation for training, use of antibiotics, active management of the third stage of labour, electronic patient records, telehealth and many more.

Unfortunately, the situation is not same in the poor and developing countries. About 800 women die from pregnancy-related complications around the world every day, out of which 99\% maternal deaths occur in developing countries, most of which could be avoided [3]. In the year 2010, 287,000 women died during and following pregnancy and childbirth in the world [4]. For a single woman who dies, there are 30 other who suffer from serious illness due to some complication of pregnancy or childbirth (a maternal morbidity) and 10 who experience a near-miss mortality (a life-threatening obstetric complication) [4].

The most important step toward improving maternal health is to effectively implement what we already have and what is already working. A large number of maternal deaths in developing countries could be prevented through appropriate applications of existing health technologies. According to WHO, health technology can be defined as the use of organized knowledge and skills in the form of equipment, devices, supplies, medicines, information materials, educational tools, procedures, techniques, and methods to solve health related issues and improve standard of life. These technologies can play a central and supportive role in many situations. For instance, in the case of shortages of trained health staff or other resource, technologies can improve both coverage and quality of care [5].

It is important to consider what improvements have been made in the available health technologies and where do we stand in this scenario. For this, we first need to identify and evaluate current health technologies and techniques and then adopt these solutions particularly in low-resource settings at the community and hospital level. Therefore, considering the importance and sensitivity of maternal health, an integrative review aimed at analyzing technological approaches and techniques in reducing the number of women dying during pregnancy and childbirth was conducted.

\section{The Review}

\subsection{Aim}

To analyze how the available technological approaches and techniques contribute in reducing the number of 
women dying during pregnancy and childbirth.

\subsection{Design}

To identify the contribution and role of health technologies and techniques in maternal health, the integrative methodology outlined in [6] was followed. A well-defined strategy was used to search the existing literature and to analyze and evaluate the data in order to locate relevant research articles. Both quantitative and qualitative reports based on the use of different health technologies and techniques for the well-being of maternal health were included. Reporting evidence from diverse sources to guide future practice and policy-making is important [7] since limitations may exist in reviewing single sources of evidence [8].

\subsection{Search Methods}

Databases: PUBMED/MEDLINE, CINAHL and COCHRANE databases were searched for the identification of relevant studies.

Search limits: The search was limited to articles published between January 2008 and June 2015 in the English language. Other filters activated were: full text available, Humans, Female, Adult: 13 - 44 years.

Search terms: The search strategy was based on a number of medical subject headings MESH terms (shown in Table 1) and text words aiming to include as many relevant articles as possible.

\subsection{Inclusion Criteria}

All types of studies meeting the following criteria were eligible for inclusion in this review. Published articles focusing on health technologies, techniques, methods, devices and medicines for pregnancy and childbirth-related complications; Studies that identify factors which affect the outcome of maternal health; studies that report the usage of any kind of health technology, associated with pregnancy and childbirth.

\subsection{Exclusion Criteria}

Exclusion criteria for this review were as follow: Articles that were in alanguage other than English; Studies about health technologies that were not related to pregnancy or childbirth; studies not focusing on the use of health technologies for maternal well-being; studies based on the use of mobiles, PDAs, and communication devices.

\subsection{Search Outcome}

A total of 1416 articles were initially identified using the search criteria from all the three databases, of which 21 were duplicated. Titles screening of the remaining 1395 articles resulted in 137 relevant articles being selected for abstract screening. The abstracts of these 137 papers were then examined resulting in 41 papers being examined in full. Out of these, 1 article was unavailable and 12 were excluded after reading the full texts. The remaining 28 studies were included in the review, as shown in PRISMA flowchart (see Figure 1). Screening of each article was done by two independent reviewers and disagreement between them was resolved by discussion. In Table 2 is presented a summary of included articles.

\section{Table 1. Search terms.}

\begin{tabular}{|c|c|}
\hline Database & Descriptors Set \\
\hline PUBMED & $\begin{array}{l}\text { (“Technology” [Mesh] OR “Biomedical Technology” [Mesh] OR “Medical Informatics” [Mesh] } \\
\text { OR “Biomedical Enhancement” [Mesh] OR “Self-Help Devices” [Mesh] } \\
\text { OR “Physical Therapy Modalities” [Mesh]) AND (“Maternal Mortality” [Mesh] } \\
\text { OR “Parturition” [Mesh] OR “Postpartum Hemorrhage” [Mesh] OR “Pregnancy, Abdominal” [Mesh]) }\end{array}$ \\
\hline COCHRANE & Technologies and techniques to reduce maternal mortality \\
\hline CINAHL & $\begin{array}{c}\text { (“Technology” OR "Biomedical Technology” OR “Medical Informatics” OR “Biomedical Enhancement” } \\
\text { OR "Self-Help Devices” OR "Physical Therapy Modalities” AND ("Maternal Mortality”] } \\
\text { OR “Parturition” OR "Postpartum Hemorrhage” OR "Pregnancy, Abdominal” }\end{array}$ \\
\hline
\end{tabular}


Table 2. Summary of the reviewed health technologies and techniques.

\begin{tabular}{|c|c|c|c|c|}
\hline Study Type & Technology/Intervention & Population & Benefits & Adverse Effects \\
\hline RCT [12] & Simulation & $\begin{array}{l}10 \text { Nurse in Control } \\
\text { Group and } 18 \text { in } \\
\text { Intervention }\end{array}$ & $\begin{array}{l}\text { Increase Student Confidence } \\
\text { in shoulder dystocia and PPH }\end{array}$ & No \\
\hline $\begin{array}{l}\text { Prospective } \\
\text { Interventional } \\
\text { Study [13] }\end{array}$ & ALSO Training & $\begin{array}{c}\text { Deliveries of } 510 \text { women } \\
\text { before Training and } 505 \\
\text { after the Training }\end{array}$ & $\begin{array}{l}\text { Incidence of PPH significantly } \\
\text { reduced and performance } \\
\text { of staff significantly improved }\end{array}$ & No \\
\hline $\begin{array}{c}\text { Descriptive } \\
\text { Study (Survey) } \\
{[14]}\end{array}$ & Interventional Radiology & $\begin{array}{l}226 \text { Obstetric } \\
\text { Units in the UK }\end{array}$ & $\begin{array}{l}\text { May work in the management } \\
\text { of Maternal Hemorrhage }\end{array}$ & Not Reported \\
\hline $\begin{array}{l}\text { Systematic } \\
\text { Review [15] }\end{array}$ & $\begin{array}{c}\text { Ambulatory Monitoring of } \\
\text { Blood Pressure }\end{array}$ & No RCT Found & $\begin{array}{c}\text { May work better in Monitoring } \\
\text { of Blood Pressure }\end{array}$ & $\begin{array}{c}\text { Not Reported } \\
\text { (Insufficient Data) }\end{array}$ \\
\hline $\begin{array}{l}\text { Descriptive } \\
\text { Study (Cross } \\
\text { Sectional } \\
\text { survey) [16] }\end{array}$ & $\begin{array}{l}\text { Information for Decision } \\
\text { Making }\end{array}$ & 146 Women & $\begin{array}{l}\text { Help in the development of } \\
\text { decision support tools and } \\
\text { in improving maternity care }\end{array}$ & No \\
\hline $\begin{array}{l}\text { Systematic } \\
\text { Review [17] }\end{array}$ & Antenatal Education & $\begin{array}{l}9 \text { RCTs with } \\
2284 \text { women }\end{array}$ & $\begin{array}{l}\text { Build women confidence } \\
\text { and prepare her for birth }\end{array}$ & No \\
\hline $\begin{array}{l}\text { Systematic } \\
\text { Review [18] }\end{array}$ & Vacuum Extraction & 10 RCTs & $\begin{array}{l}\text { Significantly less maternal trauma, } \\
\text { Caesarean Section and } \\
\text { severe maternal injuries }\end{array}$ & $\begin{array}{c}\text { Retinal } \\
\text { hemorrhage }\end{array}$ \\
\hline RCT [19] & Uterine Massage & 1964 Women & $\begin{array}{l}\text { No significant differences in } \\
\text { Blood Loss; Less effective } \\
\text { than oxytocin }\end{array}$ & No \\
\hline $\begin{array}{l}\text { Multicenter } \\
\text { RCT [20] }\end{array}$ & Uterine Massage & 2340 Women & $\begin{array}{l}\text { No significant differences } \\
\text { in Blood Loss; Less effective } \\
\text { than oxytocin }\end{array}$ & No \\
\hline $\begin{array}{l}\text { Systematic } \\
\text { Review [21] }\end{array}$ & Immersion in Water & $\begin{array}{l}8 \text { RCTs with } \\
2939 \text { Women }\end{array}$ & $\begin{array}{c}\text { use of epidural, spinal, and } \\
\text { paracervical analgesia was significantly } \\
\text { decreased; Significantly less pain }\end{array}$ & $\begin{array}{l}\text { No with a hint of } \\
\text { Insufficient Data }\end{array}$ \\
\hline $\begin{array}{l}\text { Systematic } \\
\text { Review [22] }\end{array}$ & $\begin{array}{l}\text { Exercise for preventing } \\
\text { preeclampsia }\end{array}$ & $\begin{array}{l}2 \text { small, good } \\
\text { quality trials } \\
\text { with } 45 \text { women }\end{array}$ & $\begin{array}{l}\text { No effects were found } \\
\text { (Insufficient Data) }\end{array}$ & Insufficient Data) \\
\hline $\begin{array}{l}\text { Systematic } \\
\text { Review [23] }\end{array}$ & $\begin{array}{l}\text { Elective Delivery in Di- } \\
\text { abetic Women }\end{array}$ & $\begin{array}{l}1 \text { RCT with } 200 \\
\text { insulin-requiring } \\
\text { diabetic women }\end{array}$ & $\begin{array}{l}\text { The risk of caesarean section } \\
\text { was nearly same and risk of } \\
\text { macrosomia was decreased }\end{array}$ & No \\
\hline $\begin{array}{l}\text { Systematic } \\
\text { Review [24] }\end{array}$ & Mechanical Methods & $\begin{array}{l}71 \text { RCTs with } \\
9722 \text { women }\end{array}$ & $\begin{array}{l}\text { Reduced the risk of hyperstimulation when } \\
\text { compared with vaginal prostaglandins; } \\
\text { Reduced the risk of caesarean section when } \\
\text { compared with oxytocin }\end{array}$ & $\begin{array}{l}\text { Limited data } \\
\text { available on the } \\
\text { risk of infection }\end{array}$ \\
\hline $\begin{array}{l}\text { Systematic } \\
\text { Review [25] }\end{array}$ & $\begin{array}{l}\text { Haematological } \\
\text { interventions }\end{array}$ & No RCT Found & $\begin{array}{c}\text { Not Reported } \\
\text { (Insufficient Data) }\end{array}$ & $\begin{array}{c}\text { Not Reported } \\
\text { (Insufficient Data) }\end{array}$ \\
\hline $\begin{array}{l}\text { Prospective } \\
\text { cohort 3-year } \\
\text { audit [26] }\end{array}$ & Sonography & 93 Women & $\begin{array}{l}\text { Sonography either alone or combined } \\
\text { with color Doppler imaging } \\
\text { has better diagnostic accuracy } \\
\text { in the prediction of RPOC }\end{array}$ & $\begin{array}{c}\text { Not Reported } \\
\text { (Insufficient Data) }\end{array}$ \\
\hline $\begin{array}{c}\text { Descriptive } \\
\text { Study (Survey) } \\
{[27]}\end{array}$ & $\begin{array}{l}\text { Hospital } \\
\text { Information } \\
\text { System }\end{array}$ & 30,607 deliveries & $\begin{array}{l}\text { Hospital databases are reliable } \\
\text { and accurate enough } \\
\text { to be used for monitoring purpose }\end{array}$ & No \\
\hline $\begin{array}{c}\text { Descriptive } \\
\text { Study (Survey) } \\
\text { [28] }\end{array}$ & $\begin{array}{l}\text { Hospital } \\
\text { Information } \\
\text { System }\end{array}$ & $\begin{array}{l}\text { Data about } \\
8620 \text { women }\end{array}$ & $\begin{array}{l}\text { Hospital databases can be used } \\
\text { to monitor maternal morbidity } \\
\text { and mortality and help in } \\
\text { improving health policies }\end{array}$ & No \\
\hline
\end{tabular}




\begin{tabular}{|c|c|c|c|c|}
\hline Continued & & & & \\
\hline $\begin{array}{l}\text { Systematic } \\
\text { Review [29] }\end{array}$ & $\begin{array}{l}\text { Routine } \\
\text { ultrasound in } \\
\text { late pregnancy }\end{array}$ & $\begin{array}{l}8 \text { RCTs with } \\
27,024 \text { women }\end{array}$ & $\begin{array}{l}\text { No improvements in overall } \\
\text { perinatal mortality and does } \\
\text { not confer benefit on mother or baby }\end{array}$ & $\begin{array}{l}\text { A slight increase in } \\
\text { caesarean section } \\
\text { ( Insufficient Data) }\end{array}$ \\
\hline RCT [30] & $\begin{array}{l}\text { Wearable Cardiac } \\
\text { Defibrillator in PPCM }\end{array}$ & $\begin{array}{l}107 \text { Women with } \\
\text { PPCM and } 159 \\
\text { Women with NIDCM }\end{array}$ & Reduce sudden cardiac risk in PPCM & No \\
\hline $\begin{array}{l}\text { Systematic } \\
\text { Review [31] }\end{array}$ & $\begin{array}{l}\text { Treatments for } \\
\text { iron-deficiency } \\
\text { Anemia in pregnancy }\end{array}$ & $\begin{array}{l}17 \text { small and } \\
\text { low-quality RCTs } \\
\text { with } 2578 \text { women }\end{array}$ & $\begin{array}{l}\text { Only one trial with } 125 \text { women } \\
\text { showed reduction in anemia with } \\
\text { oral iron; Intramuscular and } \\
\text { Intravenous routes better than oral }\end{array}$ & $\begin{array}{c}\text { Not Reported } \\
\text { (Insufficient Data) }\end{array}$ \\
\hline $\begin{array}{l}\text { Systematic } \\
\text { Review [32] }\end{array}$ & $\begin{array}{l}\text { Preventing Hypotension } \\
\text { during Spinal Anesthesia } \\
\text { for Caesarean Section }\end{array}$ & $\begin{array}{l}75 \text { RCTs with } \\
4624 \text { women }\end{array}$ & $\begin{array}{l}\text { In one trial (140 women) Crystalloids } \\
\text { were more effective than no fluids; } \\
\text { In another } 11 \text { trials ( } 698 \text { women) } \\
\text { colloids were more effective than } \\
\text { crystalloids; Ephedrine was significantly } \\
\text { more effective than crystalloid. }\end{array}$ & $\begin{array}{l}\text { Nausea and } \\
\text { vomiting with } \\
\text { a hint to } \\
\text { Insufficient Data }\end{array}$ \\
\hline $\begin{array}{l}\text { Systematic } \\
\text { Review [33] }\end{array}$ & $\begin{array}{l}\text { Pain management for } \\
\text { women in labour }\end{array}$ & 18 Reviews with 310 Trials & $\begin{array}{l}\text { Results are categorized in } \\
\text { What works, what may work and } \\
\text { limited data in Discussion Section }\end{array}$ & $\begin{array}{l}\text { Pharmacological } \\
\text { method is more } \\
\text { effective but has } \\
\text { more adverse effect }\end{array}$ \\
\hline $\begin{array}{l}\text { Systematic } \\
\text { Review [34] }\end{array}$ & $\begin{array}{l}\text { Active Management of } \\
\text { Third Stage of Labour }\end{array}$ & $\begin{array}{l}7 \text { RCTs with } \\
5390 \text { women }\end{array}$ & $\begin{array}{l}\text { Decreased caesarean section very } \\
\text { slightly and reduced labour time } \\
\text { (less than } 12 \text { hours) }\end{array}$ & No \\
\hline $\begin{array}{l}\text { Systematic } \\
\text { Review [35] }\end{array}$ & $\begin{array}{l}\text { Active Management of } \\
\text { Third Stage of Labour }\end{array}$ & $\begin{array}{l}12 \text { RCTs with } \\
7792 \text { women }\end{array}$ & $\begin{array}{l}\text { Decreased caesarean section very } \\
\text { slightly and reduced labour time } \\
\text { (less than } 12 \text { hours) }\end{array}$ & No \\
\hline $\begin{array}{l}\text { Cluster } \\
\text { Randomized } \\
\text { Trial [36] }\end{array}$ & $\begin{array}{c}\text { Non-Pneumatic } \\
\text { Anti-Shock Garment }\end{array}$ & $\begin{array}{c}38 \text { Primary } \\
\text { Health Centers } \\
\text { with } 880 \text { Women }\end{array}$ & $\begin{array}{l}\text { Significant rapid shock recovery; } \\
\text { Reduce maternal Mortality }\end{array}$ & No \\
\hline Review [37] & $\begin{array}{l}\text { Uterine Balloon } \\
\text { Tamponade }\end{array}$ & Literature Search & Effective in management of PPH & Insufficient Data \\
\hline $\begin{array}{l}\text { Systematic } \\
\text { Review [38] }\end{array}$ & Partograph & $\begin{array}{l}6 \text { RCTs with } \\
7706 \text { women }\end{array}$ & $\begin{array}{l}\text { Slight reduction in caesarean section } \\
\text { and instrumental vaginal delivery }\end{array}$ & $\begin{array}{l}\text { Not Reported } \\
\text { (Insufficient Data) }\end{array}$ \\
\hline $\begin{array}{l}\text { Systematic } \\
\text { Review [39] }\end{array}$ & Magnesium Sulphate & 15 trials & $\begin{array}{l}\text { Reduced risk of eclampsia } \\
\text { by more than } 50 \%\end{array}$ & Flushing \\
\hline
\end{tabular}

\subsection{Quality Assessment}

It is always difficult to evaluate the quality of diverse primary sources in a meaningful way [6]. Methodological quality assessment was not performed in this review because assignment of such assessment score in heterogeneous studies is an 'arbitrary and unscientific process [9]. Tools like [10] and the Joanna Briggs Institute (JBI) were used to assess the quality of included studies. However, studies quality was not summarized due to the inherited methodological complexity [6].

\subsection{Data Extraction and Synthesis}

Extracting and synthesizing data from heterogeneous sources is a complex process [11]. All 28 papers were independently assessed by two authors. The following information was abstracted from the included studies. (a) General information about authors, journal, publication date, country and language (b) Research design, location, participants, aim (c) Sampling method, sample size (d) Evidence of use of health technologies for women during pregnancy and childbirth (e) Results and descriptive summaries of numerical data. Synthesis of the data involved categorizing health technologies and techniques by their characteristics, narrating and summarizing its use and effects, and presenting data visually. 


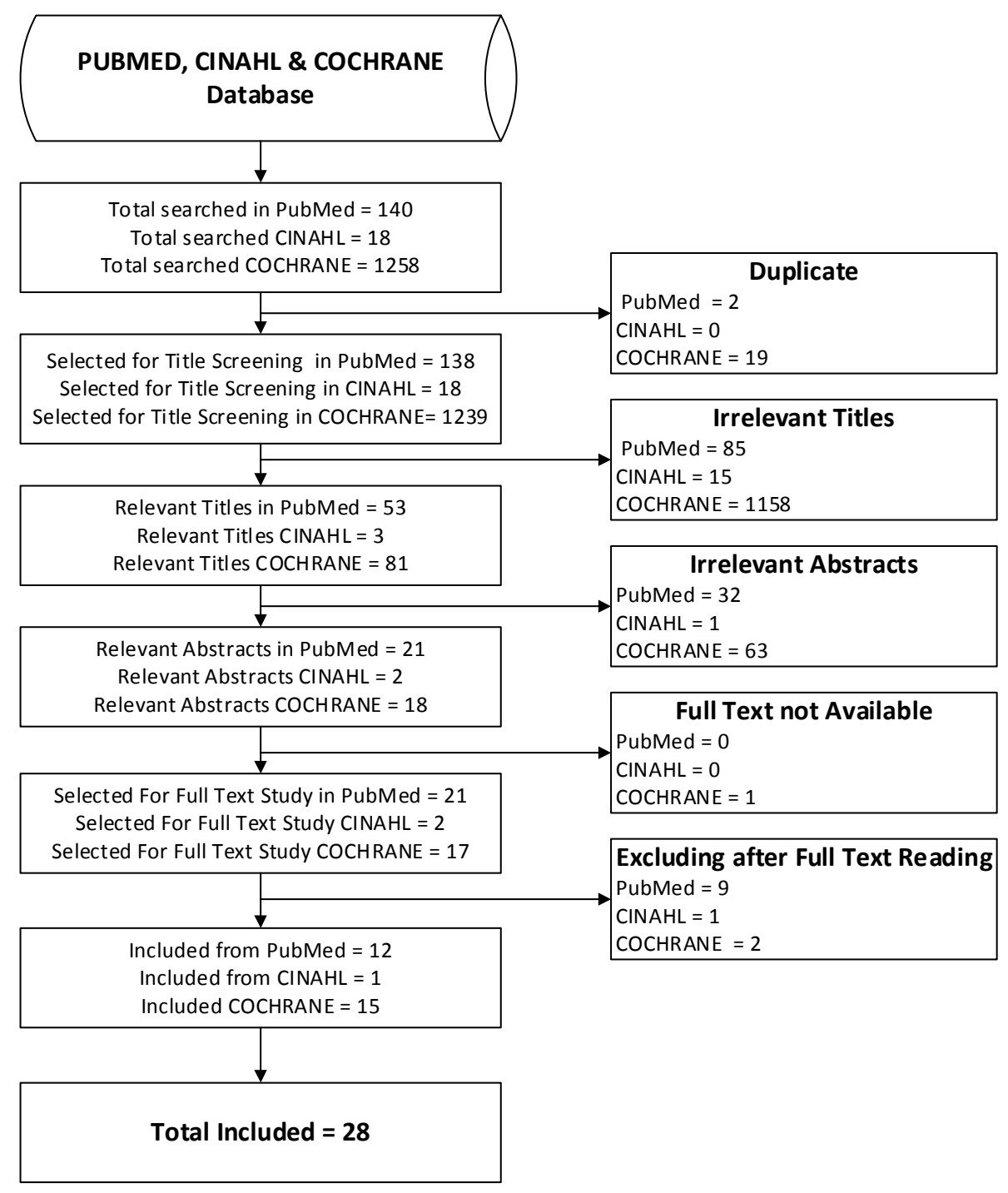

Figure 1. Flow chart showing the process of identification and screening.

\section{Results}

Of these 28 included studies, 16 were systematic reviews, 3 were randomized control trials, 1 multicenter RCT, 1 cluster randomized trial, 1 prospective cohort study, 1 prospective interventional study, 1 literature review and 4 were descriptive studies. Thirteen studies were based in the UK, four in the USA, three in Australia and one study each in Denmark, Switzerland, Venezuela, Canada, France, Brazil, Croatia and South Africa.

The sampled participants were pregnant women aged between 13 to 44 years in all the included studies. All studies have assessed different health technologies during the labour and childbirth and have highlighted and evaluated the studied technologies along with its benefits and performance results. These studies have also showed and explained the usefulness of different health technologies in different situations and settings for PPH, eclampsia, third stage oflabour and pain during labour etc. Technologies used in these 28 articles are explained in the Discussion section while their summarized results are provided in Table 2.

\section{Discussion}

Sufficient evidence of effectiveness for different health technologies and techniques in many situations have been identified by this review. For example, in the case of shortages of trained health staff or low resource settings, some technologies can affect both coverage and quality of care. Our results indicate that health care tech- 
nologies have the potential to play an important role in the reduction of maternal mortality. The reviewed technologies are further discussed as follows.

\subsection{Educating and Training for Health Care Professionals and Mothers}

Simulation: The reproduction or replication of some real-world process, scenario or act is called simulation. Simulation can be used as an effective tool for educating and training health care professionals as it allows the opportunity to make mistakes in a safe environment without doing any harm to real patients [40]. High-fidelity simulations are particularly effective in training health professionals to manage and assess complex clinical scenarios. The more the simulation replicates realistic experience, the more is the level of fidelity [41]. The usefulness of high-fidelity simulations for the obstetric emergencies of shoulder dystocia and postpartum hemorrhage were shown to be very effective in educating and training nurses [12]. These results are also consistent with the results of other published research, for example [42], where the use of simulation for education and training is highly effective for health care professionals.

ALSO Training for PPH: Advanced Life Support in Obstetrics (ALSO) was developed by the American Academy of Family Physicians and is one of the most widely used Emergency Obstetrics Care course. A prospective interventional study [13] was conducted in Tanzania in 2008 to compare staff performance and incidence of PPH before and after ALSO course. After the ALSO training the incidence of PPH (blood loss $\geq 500$ $\mathrm{ml}$ ) was significantly reduced from $32.9 \%$ to $18.2 \%$ [RR 0.55 , 95\% CI: 0.44 - 0.69] and severe PPH (blood loss $\geq 1000 \mathrm{ml}$ ) from 9.2 to $4.3 \%$ [RR 0.47, 95\% CI: 0.29 - 0.77]. The performance of staff was significantly improved and the identification of PPH through visual observation improved from 1 out 25 cases to 1 out of 5 cases.

Information for Decision Making about birth Facility: The quality of maternity care and clinical capabilities is usually different in different hospitals and birth centers. It is important to facilitate pregnant women to identify and choose the birth facility of their choice and preferences. The effectiveness of such facilitation and decision-making tools depends on the extent, nature and quality of information provided to users [43]. According to the participants in [16], the highly preferred information by mothers includes policies about an accompanying partner, other women's opinions about the facility, right to choose one's preferred position during labour and birth, quality of the care provided to the facility and access to on-site neonatal ICU. On the other hand, information regarding an actual number of certain medical procedures (e.g., induction of labour, episiotomy, caesarean section) performed in the facility was not of much interest.

Antenatal education for childbirth or parenthood: Antenatal education is provided to a large percentage of pregnant women worldwide in the US, UK, Canada, Mexico, Brazil, Finland, Germany, Australia, Japan, and China etc. by many maternity care providers, public health departments, hospitals and private agencies [17]. In other parts of the world, there are no formal antenatal educational programs and mostly the knowledge and experience of birth and care is passed from mothers to daughters and from traditional birth attendants to their attendees. Combined family livings in which several generations use to live in one place were also a source of education and experience of birth. But as these traditional methods of information sharing have declined, the need for a structured education for childbirth and parenthood is increased. The primary aim of any antenatal education programs should be to build women confidence in giving birth, to prepare her for parenthood and contribute to reducing perinatal morbidity and mortality. For this to achieve we need large and well-designed clinical trials to answer the question of its effectiveness.

\subsection{Obstetric Hemorrhage}

Interventional Radiology for the Management of Obstetric Hemorrhage: One of the major causes of maternal mortality worldwide is obstetric hemorrhage (OH) [44]. Since 1970 Interventional Radiology (IR) with iliac artery embolization has been proposed as a treatment of OH [45]. Selective use of IR with arterial balloon occlusion or embolization may reduce overall blood loss and improve surgical outcome in treating massive maternal hemorrhage [46]. A national survey [14] using postal questionnaire was conducted in the UK in 2007 to investigate the availability and use of IR and its effectiveness in controlling $\mathrm{OH}$. The availability and standard application of IR for OH were limited to large hospitals. In smaller hospitals either the resources was not there or the required expertise was not available. Future research is highly desirable in order to establish the exact role of IR techniques in the management of $\mathrm{OH}$. 
Uterine Massage for Reducing PPH: Uterine Massage stimulates uterine contraction and is believed to reduce hemorrhage due to the release of local prostaglandin [47]. However, there has been very little experimental research to assess the effectiveness of this method. Results obtained in RCTs [19] [20], shows that uterine massage is less effective than oxytocin in reducing blood loss after delivery and there was no additional benefit when compared with of oxytocin alone.

Active Management of Third Stage of Labor (AMTSL): It is a clinical protocol, highly effective in preventing PPH. It consists of early intervention with amniotomy and oxytocin in order to increase the frequency and intensity of uterine contractions and one-to-one care [48]. The aim of AMTSL is to facilitate obstetric care in a busy labour ward and to reduce the high rate of caesarean sections [49]. However, active management decrease caesarean section and labour time very slightly as shown in a review [34] with 7 trials involving 5390 women and in [35] with 12 trials involving 7792 women. No other effects regarding assisted vaginal deliveries or maternal or neonatal morbidity were found. It is highly possible that some parts of the active management package are more effective than others and further evaluation would be needed to investigate this.

Non-Pneumatic Anti-Shock Garment (NASG): Non-pneumatic Anti-Shock Garment (NASG) is a first-aid device that may help women survive delays in transport by compressing the lower body with nine articulated segments closed tightly around the legs, pelvis, and abdomen. Any vaginal or abdominal procedures or external uterine massage can be performed easily while NASG is put on. The majority of the pressure exerted by NASG is in the abdomen and pelvis thereby reducing immediately the blood flow once applied in obstetric hemorrhage [50]. The 54\% reduced odds of maternal mortality and the significantly rapid shock recovery with no risk of safety issues suggest that as NASG can be used for quick shock reversal and as a first-aid device at the primary health care centers and ambulances level [36]. Both uterotonics and NASG should be considered in health systems (uterotonics to prevent and treat PPH and NASG for rapid shock reversal)

Uterine Balloon Tamponade: Obstetric Hemorrhage is one of the major causes of maternal mortality worldwide [51]. Recently, uterine balloon tamponade has been added to the guidelines for the management of $\mathrm{PPH}$ [52]. In this case, the balloon is inserted into the uterus and then inflated which help decrease or stop bleeding. There are different types of balloons available including the Bakri, Foley, Sengstaken-Blakemore, Rusch and condom catheter. A recent review in [37] confirms the effectiveness of uterine tamponade using intrauterine balloons in the management of PPH with minimal adverse effects. Overall, from the case reports, retrospective studies [53] [54] and prospective studies [55] [56], 91.5\% cases were successful where different balloons have been used.

Partograph: Partograph or Partogram is one of the most important tools to ensure timely management of obstructed labour [57]. It is a tool that graphically represents key events during labour usually in the form of a pre-printed paper. With the help of partograph, midwives and obstetricians are able to discover slow progress in labour, and hence, start appropriate interventions to prevent prolonged and obstructed labour [58]. WHO conducted a prospective multicenter study [59] to establish the effectiveness of composite WHO partograph in 35,484 women in South East Asia. This composite intervention reduced prolonged labour from 6.4\% to 3.4\% and the proportion of augmented labour from 20.7\% to 9.1\%. Emergency caesarean births decreased from $9.9 \%$ to $8.3 \%$ and intrapartum stillbirths from $0.5 \%$ to $0.3 \%$. However, another review in [38] does not shows any firm evidence whether using a Partogram decrease or increase caesarean section rates or had any effect on other aspects of labour. Further trials are needed to identify the effect of partograph on the outcomes of labour in different settings.

Haematological Interventions for Treating DIC during Pregnancy: Disseminated intravascular coagulation (DIC) is an acquired syndrome characterized by intravascular blood clotting in the blood vessels and is the result of pathologic overstimulation of the coagulation system [60]. DIC can lead to organ dysfunction and bleeding because of depletion of platelets in pregnant women. In [25] the usefulness of haematological interventions was to be studied for treating DIC during pregnancy and postpartum but no RCT was found to be included in the review.

Sonographic \& Clinical Parameters in the Prediction of Retained Product of Conception (RPOC): Secondary PPH with possibly pain and fever is the most common clinical symptom of retained products of conception (RPOC), an incidence reported around 1\% of all deliveries in the literature [61]. For the diagnosis of RPOC different clinical symptoms as well as sonographic assessment are used [62]. Once the diagnosis is done, evacuation of the RPOC is performed in approximately 70\% of patients referred with secondary PPH [63]. Evacuation of the RPOC is usually a simple and a safe procedure. However, samples obtained after the primary 
evacuation of the uterus shows some false positive findings for gestational remains (28.9\% if the diagnosis is based on sonography and $51.5 \%$ if it is based on clinical examination) [64]. In a prospective cohort 3-year audit [26], the diagnostic accuracy of different clinical and sonographic parameters in the prediction and management of RPOC in the late postpartum period was assessed. The results confirm that sonography either alone or combined with color Doppler imaging provide statistically significant accuracy than the usual clinical parameters in the prediction of RPOC.

\subsection{Hypertension}

Ambulatory Monitoring of Blood Pressure (ABPM): One of the most common medical complications of pregnancy is hypertension. Accurate and timely measurement of blood pressure is important throughout the course of pregnancy. The effectiveness of conventional measurement of blood pressure has been questioned and cross-examined in recent years. Several efforts have been made to improve blood pressure measurement using ambulatory automated devices. These devices continuously and automatically measure blood pressure over a period of time while patients are busy doing their day to day activities. However, the authors in [15] find no RCTs to investigate the use of ABPM during pregnancy and hence it cannot be stated whether wearing a blood pressure monitoring device for 24 hours during pregnancy is effective in detecting hypertension.

Exercise for Preventing Pre-Eclampsia: In many cultures and societies it is believed that if women are not physically active during the later stage of her pregnancy, labour may be more difficult [65]. Therefore, some studies (case-control studies) recommend physical exercise in order to reduce the risk of pre-eclampsia and gestational hypertension [66]. However, no effects of exercise or increased physical activity were found in the prevention of pre-eclampsia and its complications (review of 2 small, good quality trials with 45 women) [22]. There was insufficient data and hence, no reliable conclusions could be made. The extent and nature of physical activity during pregnancy should, therefore, be decided by the individual women in consultation with their physicians.

Preventing Hypotension during Spinal Anesthesia for Caesarean Section: Spinal anesthesia is commonly used for a caesarian section because it keeps the mother awake during birth and avoids the risks of general anesthesia. However, spinal anesthesia may cause hypotension which in its severe form is very risky for both the mother and baby [32]. In a systematic review in [32], the authors studied the effects of prophylactic interventions for hypotension following spinal anesthesia for caesarean section. Crystalloids were found more effective than no fluids (relative risk 0.78 , 95\% CI 0.60 to 1.00 ) in one trial with 140 women while colloids were more effective than crystalloids (RR 0.68, 95\% CI 0.52 to 0.89 ) in another 11 trials with 698 women. Similarly, in 7 trials with 470 women Ephedrine was significantly more effective than crystalloid. The review could not found any single method that could completely prevent hypotension. There was also insufficient data regarding the adverse effects.

Magnesium Sulphate: Pre-eclampsia is usually associated with raised blood pressure and proteinuria. Most women with pre-eclampsia give birth without problems. However, severe pre-eclampsia can cause problems like kidney failure, stroke, blood clotting and liver failure [67]. On the other hand, Eclampsia, the occurrence of a seizure in association with pre-eclampsia, is rare but potentially life-threatening. Magnesium sulphate is the most promising drug which reduces the risk of eclampsia by more than 50\% [39]. It should be available in all hospitals providing care for pregnant women with eclampsia and pre-eclampsia. It is more appropriate for lowresource settings due to its easy availability and inexpensiveness.

\subsection{Pain Management}

Immersion in Water in Pregnancy, Labour and Birth: The application of warm water immersion during pregnancy, labour and birth for relaxation and pain relief is being discussed since long [68]. It is usually easier for women to adjust her position in the water and to increase her comfort during labour and childbirth [69]. The warmth of the water may cause muscle relaxation and reduce anxiety, decreasing the release of catecholamine and motivate the release of endorphins [70]. However, some believe that immersion in water during labour and birth poses some risks to women or babies, for example, inhalation of water by the newborn and maternal or neonatal infections [21]. A review (8 RCTs with 2939 women) conducted in [21], found that maternal pain and the use of epidural, spinal or paracervical analgesia is decreased with the application of water immersion during the first stage of labour. Furthermore, the study found no adverse effects. However, no evidence could be found 
about the effects of water immersion in the third stage of labour.

Pain Management for Women in Labour: Pharmacological and non-pharmacological interventions to manage pain in labour are classified into 3 categories [33]. What Works: Epidural, combined spinal epidural (CSE) and inhaled analgesia effectively manage pain in labour, but may give rise to adverse effects. CSE relieve pain more quickly than traditional or low-dose epidurals. Inhaled analgesia more likely cause vomiting, nausea and dizziness while epidural analgesia more likely result in hypotension, motor blockade, fever or urinary retention. What May Work: There is some evidence from single trials, which suggest that acupuncture, immersion in water, local anesthetic nerve blocks and massage may improve management of pain during labour, with few adverse effects. Insufficient Evidence: No clear judgment can be made regarding the use of hypnosis, biofeedback, sterile water injection, aromatherapy, TENS, or parenteral opioids for pain management in labour due to the lack of sufficient evidence. Most methods of non-pharmacological pain management appear to be safe with no adverse effects for mother and baby, however, their effectiveness is unclear, due to insufficient data.

\subsection{Delivery}

Vacuum Extraction for Assisted Vaginal Delivery: Vacuum Extractor, an alternative to forceps delivery, is a metal or plastic cup which is attached to the baby's head to help guide him/her out of the birth canal and is used to assist pregnant women in vaginal delivery. Use of the vacuum extractor, when compared to forceps delivery, is associated with significantly less maternal trauma (odds ratio $0.41,95 \%$ CI 0.33 to 0.50 ) and with less general anesthesia as shown in [18]. It is also associated with more deliveries (odds ratio 1.69, 95\% CI 1.31 to 2.19) and fewer caesarean sections. However neonatal cephalohematoma and retinal hemorrhage are increased in the vacuum extraction. The study shows that the vacuum extractor is significantly less likely to perform a successful vaginal delivery than forceps. There may be a number of reasons for this. The most prominent could be errors in technique e.g. incorrect cup use or pulling in the wrong direction.

Elective Delivery in Diabetic Pregnant Women: 90\% cases of diabetes complicating pregnancy are gestational diabetes with varying complications according to the type of diabetes and the intensity of the disease [23]. In pregnancies with pregestational diabetes, the major concerns during the third trimester are late fetal death, complications of premature delivery and birth trauma associated with fetal macrosomia [71]. A review (one trial with 200 insulin-requiring diabetic women) in [23] was conducted to assess the effect of elective delivery compared to expectant management in diabetic pregnant women. There was not enough evidence and hence no firm conclusion can be drawn.

Mechanical Methods: Induction of labour is the beginning of labour before its start naturally. Sometimes it is safer for women to induce her labour artificially at some feasible gestational age. The aim of induced labour is to achieve vaginal delivery and can be either initiated using the mechanical or pharmacological method. The choice between mechanical and pharmacological methods usually depends on the experience of the practitioner and availability and requirements of the method. A review in [24] with 71 RCTs (9722 women) was conducted to compare mechanical methods used for third-trimester labour induction. Caesarean section rates were found similar to mechanical methods and prostaglandins. Mechanical methods are as effective in achieving delivery within 24 hours of intervention as any prostaglandins but reduced the risk of hyper-stimulation with fetal heart rate changes when compared with vaginal prostaglandins. However, when compared with oxytocin, mechanical methods reduce the risk of caesarean section (5 studies; 398 women, RR 0.62; 95\% CI 0.42 to 0.90 ). Due to the limited data available on severe maternal morbidity, the risk of infection and patient satisfaction or patient preferences, no firm conclusion can be drawn in this regard.,

\subsection{Miscellaneous Approaches}

Hospital Information System: Hospital information systems (HIS) are a useful tool for estimating and monitoring maternal mortality and severe maternal morbidity. They can be used to set health priorities and optimize the performance of health care facilities. Hospital records are rapidly available, and inexpensive to use, however, before using, its validity must be thoroughly assessed. Chantry et al in [27] analyzed the accuracy of hospital databases in four French teaching hospital discharge data in 2006-2007, covering 30,607 deliveries. They concluded that $95 \%$ of recording errors were in such a way that it could be easily corrected. The study suggests that hospital administrative database is reliable and accurate enough and that it could be used for monitoring purpose. Similarly, in [28] HIS data about 8620 women from the Municipal Secretariat of Health in Southeastern Brazil 
was analyzed for severe maternal mortality and morbidity. Prevalence of maternal morbidity was found to 37.8/1000 women, and that of mortality was 12/100,000 women. The authors confirm the usability and reliability of HIS in reporting maternal morbidity and mortality. Such type of information system can be used to improve our understanding and contribute to the enhancement of the quality of care provided to women during pregnancy, delivery and the postnatal period.

Routine Ultrasound in Late Pregnancy: Ultrasound is a sophisticated electronic technology in which a transducer (which emits ultrasound frequency) is moved across the area of the body to be examined. The pulses propagate through the tissues, where some are reflected back to the transducer, which are then processed by a computer where each echo is shown as an image on the screen. Ultrasound can be used in late pregnancy to assess the baby's condition and abnormalities, which may not otherwise be evident. However routine late pregnancy ultrasound in low-risk populations was not associated with improvements in overall perinatal mortality and does not confer a benefit on mother or baby (8 trials including 27,024 women) [29]. Routine ultrasound in late pregnancy may slightly increase caesarean section rates, however, there is not sufficient evidence about long-term neonatal and childhood outcome.

Wearable Cardiac Defibrillator in PPCM: In last trimester of pregnancy, women usually show a rare type of cardiomyopathy called peripartum cardiomyopathy (PPCM) [30]. Wearable Cardiac Defibrillator (WCD) automatically monitors the patient's electrocardiograms and also records total wear time and can deliver a biphasic defibrillation pulse if ventricular tachycardia or ventricular fibrillation is detected [72]. The outcomes of women with PPCM versus non-ischemic dilated cardiomyopathy (NIDCM) in non-pregnant similarly aged women referred for a WCD were explored and compared in [30]. The analysis was done on 107 patients with PPCM and 159 patients with NIDCM. The average use duration of the WCD was $124 \pm 123$ days (median 86.5 days) for the PPCM patients, and $96 \pm 83$ days (median 76.0 days) for the NIDCM patients. The outcomes show a mortality rate of 2.8\% in PPCM patients which is lower than previously published results. Early PPCM ventricular improvements were high and 26\% of women showed improvement within 3 months of WCD referral. WCD therapy may reduce sudden cardiac risk in PPCM and need further prospective studies for detailed assessment.

Treatments for Iron-Deficiency Anemia in Pregnancy: Anemia in pregnancy is defined by the World Health Organization as a hemoglobin value below $11 \mathrm{~g} / \mathrm{dl}$ [73]. The common causes of anemia include iron deficiency, folate deficiency, vitamin B12 deficiency, bone marrow suppression, malaria, chronic blood loss and underlying malignancies [74]. During pregnancy, there is an increase in both red blood cells and plasma volume due to the needs of the growing fetus which results in a reduction of the concentration of hemoglobin in the blood [75]. Severe anemia can be very harmful to mothers and babies, but the risks of mild and moderate anemia are controversial. It is still unknown whether treating mild or moderate anemia have any adverse effect on pregnant women. For this purpose, the effects of different treatments for iron-deficiency anemia is assessed in a review [31] with 17 small and low-quality trials involving 2578 women. Only one trial with 125 women showed a reduction in anemia with oral iron (relative risk 0.38; 95\% CI 0.26 to 0.55 ). There was not enough data on the effects of treatment according to the severity of anemia and also on adverse effects. Although the intramuscular and intravenous routes showed better results than the oral route, with no assessment of clinical outcomes and adverse effects.

\section{Conclusions}

There are a number of health technologies and techniques which are relatively simple to develop and safe to apply and it has no adverse effects. These includes different type of high-fidelity simulations and training programs, educational and awareness programs for women and communities, decision support tools and Hospital Information Systems. Governments, hospitals and care providers should make policies about the development and implementation of such type of programs. Similarly, technologies like Active management of the third Stage of Labour, Magnesium Sulphate, Uterine Balloon Tamponade, Wearable Cardiac Defibrillator and Non-Pneumatic Anti-Shock Garment (NASG) should be core components of every maternity care unit as it shows promising results with no serious adverse effects. Besides that, high-quality RCTs are still needed to assess the effectiveness and exact role of Interventional radiology, Ambulatory Monitoring of Blood Pressure, Vacuum Extraction, Immersion in Water, Mechanical Methods for induction of labour, Haematological interventions, Transcutaneous Electro Stimulation and Partographs in the prevention and reduction of maternal mortality.

Further research is recommended to assess and establish the role of health technologies in reducing maternal mortality. Technology-based solutions can fill the gap in health resources, knowledge and expertise when pro- 
vided by appropriate care provider with proper skills and with community support. Health and technology researchers must be motivated to continue improving existing solutions and finding a new one for problems that endanger women and their babies while at the same time governments, care providers and private health organizations must be forced and convinced to apply available technological approaches.

\section{References}

[1] Chalmers, B., Mangiaterra, V. and Porter, R. (2001) WHO Principles of Perinatal Care: The Essential Antenatal, Perinatal, and Postpartum Care Course. Birth, 28, 202-207. http://dx.doi.org/10.1046/j.1523-536x.2001.00202.x

[2] Bill \& Melinda Gates Foundation (2010) Global Strategy for Women’s and Children’s Health, Section 5 “New and Emerging Medical Technologies".

[3] Hogan, M.C., Foreman, K.J., Naghavi, M., Ahn, S.Y., Wang, M., Makela, S.M., Lopez, A.D., Lozano, R. and Murray, C.J. (2010) Maternal Mortality for 181 Countries, 1980-2008: A Systematic Analysis of Progress towards Millennium Development Goal 5. Lancet, 375, 1609-1623. http://dx.doi.org/10.1016/S0140-6736(10)60518-1

[4] Lewis, G. (2003) Beyond the Numbers: Reviewing Maternal Deaths and Complications to Make Pregnancy Safer. British Medical Bulletin, 67, 27-37. http://dx.doi.org/10.1093/bmb/ldg009

[5] Hankar, A., Bartlett, L., Fauveau, V., Islam, M., Terreri, N. and Countdown to 2015 Maternal Health Group (2008) Delivery of MDG 5 by Active Management with Data. Lancet, 371, 1223-1224.

[6] Whittemore, R. and Knafl, K. (2005) The Integrative Review: Updated Methodology. Journal of Advanced Nursing, 52, 546-553. http://dx.doi.org/10.1111/j.1365-2648.2005.03621.x

[7] Mays, N., Pope, C. and Popay, J. (2005) Systematically Reviewing Qualitative and Quantitative Evidence to Inform Management and Policy-Making in the Health Field. Journal of Health Services Research \& Policy, 10, 6-20.

[8] Flemming, K. (2007) The Knowledge Base for Evidence-Based Nursing: A Role for Mixed Methods Research? Advances in Nursing Science, 30, 41-51. http://dx.doi.org/10.1097/00012272-200701000-00005

[9] Meade, M.O. and Richardson, W.S. (1997) Selecting and Appraising Studies for a Systematic Review. Annals of Internal Medicine, 127, 531-537. http://dx.doi.org/10.7326/0003-4819-127-7-199710010-00005

[10] CASP (2013) 10 Questions to Help You Make Sense of Qualitative Research. Qualitative Research Checklist,

[11] Goldsmith, M.R., Bankhead, C.R. and Austoker, J. (2007) Synthesising Quantitative and Qualitative Research in Evidence-Based Patient Information. Journal of Epidemiology \& Community Health, 61, 262-270. http://dx.doi.org/10.1136/jech.2006.046110

[12] Andrighetti, T.P., Knestrick, J.M., Marowitz, A., Martin, C. and Engstrom, J.L. (2011) Shoulder Dystocia and Postpartum Hemorrhage Simulations: Student Confidence in Managing These Complications. Journal of Midwifery \& Women's Health, 57, 55-60. http://dx.doi.org/10.1111/j.1542-2011.2011.00085.x

[13] Sorensen, B.L., Rasch, V., Massawe, S., Nyakina, J., Elsass, P. and Nielsen, B.B. (2011) Advanced Life Support in Obstetrics (ALSO) and Post-Partum Hemorrhage: A Prospective Intervention Study in Tanzania. Acta Obstetricia et Gynecologica Scandinavica, 90, 609-614. http://dx.doi.org/10.1111/j.1600-0412.2011.01115.x

[14] Webster, V.J., Stewart, R. and Stewart, P. (2010) A Survey of Interventional Radiology for the Management of Obstetric Haemorrhage in the United Kingdom. International Journal of Obstetric Anesthesia, 19, 278-281. http://dx.doi.org/10.1016/j.ijoa.2009.10.010

[15] Bergel, E., Carroli, G. and Althabe, F. (2002) Ambulatory versus Conventional Methods for Monitoring Blood Pressure during Pregnancy. Cochrane Database of Systematic Reviews, 2, Article NO.: CD001231. http://dx.doi.org/10.1002/14651858.CD001231

[16] Thompson, R. and Wojcieszek, A.M. (2012) Delivering Information: A Descriptive Study of Australian Women’s Information Needs for Decision-Making about Birth Facility. BMC Pregnancy Childbirth, 12, 51. http://dx.doi.org/10.1186/1471-2393-12-51

[17] Gagnon, A.J. and Sandall, J. (2007) Individual or Group Antenatal Education for Childbirth or Parenthood, or Both. Cochrane Database of Systematic Reviews, 3, Article NO.: CD002869. http://dx.doi.org/10.1002/14651858.CD002869.pub2

[18] Johanson R, Menon V. (2010) Vacuum Extraction versus Forceps for Assisted Vaginal Delivery. Cochrane Database of Systematic Reviews, 11, Article NO.: CD000224. http://dx.doi.org/10.1002/14651858.CD000224.pub2

[19] Abdel-Aleem, H., Singata, M., Abdel-Aleem, M., Mshweshwe, N., Williams, X. and Hofmeyr, G.J. (2010) Uterine Massage to Reduce Postpartum Hemorrhage after Vaginal Delivery. International Journal of Gynecology \& Obstetrics, 111, 32-36. http://dx.doi.org/10.1016/j.ijgo.2010.04.036

[20] Chen, M., Chang, Q., Duan, T., He, J., Zhang, L. and Liu, X. (2013) Uterine Massage to Reduce Blood Loss after Va- 
ginal Delivery: A Randomized Controlled Trial. Obstetrics \& Gynecology, 122, 290-295. http://dx.doi.org/10.1097/AOG.0b013e3182999085

[21] Cluett, E.R. and Burns, E. (2009) Immersion in Water in Labour and Birth. Cochrane Database of Systematic Reviews, 2, Article NO.: CD000111. http://dx.doi.org/10.1002/14651858.CD000111.pub3

[22] Meher, S. and Duley, L. (2006) Exercise or Other Physical Activity for Preventing Pre-Eclampsia and Its Complications. Cochrane Database of Systematic Reviews, Article NO.: CD005942. http://dx.doi.org/10.1002/14651858.CD005942

[23] Boulvain, M., Stan, C.M. and Irion, O.M. (2001) Elective Delivery in Diabetic Pregnant Women (Review). Cochrane Database of Systematic Reviews, 4, Article NO.: CD001997. http://dx.doi.org/10.1002/14651858.CD001997

[24] Jozwiak, M., Bloemenkamp, K.W.M., Kelly, A.J., Mol, B.W.J., Irion, O. and Boulvain, M. (2012) Mechanical Methods for Induction of Labour. Cochrane Database of Systematic Reviews, 3, Article NO.: CD001233. http://dx.doi.org/10.1002/14651858.CD001233.pub2

[25] Martí-Carvajal, A.J., Comunián-Carrasco, G. and Peña-Martí, G.E. (2011) Haematological Interventions for Treating Disseminated Intravascular Coagulation during Pregnancy and Postpartum. Cochrane Database of Systematic Reviews, 3, Article NO.: CD008577. http://dx.doi.org/10.1002/14651858.CD008577.pub2

[26] Matijevic, R., Knezevic, M., Grgic, O. and Zlodi-Hrsak, L. (2009) Diagnostic Accuracy of Sonographic and Clinical Parameters in the Prediction of Retained Products of Conception. Journal of Ultrasound in Medicine, 28, 295-299.

[27] Chantry, A.A., Deneux-Tharaux, C., Cans, C., Ego, A., Quantin, C., Bouvier-Colle, M.H. and GRACE Study Group (2011) Hospital Discharge Data Can Be Used for Monitoring Procedures and Intensive Care Related to Severe Maternal Morbidity. Journal of Clinical Epidemiology, 64, 1014-1022. http://dx.doi.org/10.1016/j.jclinepi.2010.11.015

[28] Magalhães, M.D.C. and Bustamante-Teixeira, M.T. (2012) Severe Acute Maternal Morbidity: Use of the Brazilian Hospital Information System. Revista de Saúde Pública, 46, 472-478. http://dx.doi.org/10.1590/S0034-89102012005000029

[29] Bricker, L., Medley, N. and Pratt, J.J. (2015) Routine Ultrasound in Late Pregnancy (after 24 Weeks' Gestation). Cochrane Database of Systematic Reviews, 6, Article NO.: CD001451. http://dx.doi.org/10.1002/14651858.CD001451.pub4

[30] Saltzberg, M.T., Szymkiewicz, S. and Bianco, N.R. (2012) Characteristics and Outcomes of Peripartum versus Nonperipartum Cardiomyopathy in Women Using a Wearable Cardiac Defibrillator. Journal of Cardiac Failure, 18, 21-27. http://dx.doi.org/10.1016/j.cardfail.2011.09.004

[31] Reveiz, L., Gyte, G.M.L. and Cuervo, L.G. (2010) Treatments for Iron-Deficiency Anaemia in Pregnancy (Review). Cochrane Database of Systematic Reviews, 2, Article NO.: CD003094. http://dx.doi.org/10.1002/14651858.CD003094.pub2

[32] Cyna, A.M., Andrew, M., Emmett, R.S., Middleton, P. and Simmons, S.W. (2010) Techniques for Preventing Hypotension during Spinal Anaesthesia for Caesarean Section. Cochrane Database of Systematic Reviews, 10, Article NO.: CD002251. http://dx.doi.org/10.1002/14651858.CD002251.pub2

[33] Jones L, Othman M, Dowswell T, Alfirevic Z, Gates S, Newburn M., et al. (2012) Pain Management for Women in Labour: An Overview of Systematic Reviews. Cochrane Database of Systematic Reviews, 6, Article NO.: CD009234. http://dx.doi.org/10.1002/14651858.CD009234.pub2

[34] Brown, H.C., Paranjothy, S., Dowswell, T. and Thomas, J. (2013) Package of Care for Active Management in Labour for Reducing Caesarean Section Rates in Low-Risk Women. Cochrane Database of Systematic Reviews, 9, Article NO.: CD004907. http://dx.doi.org/10.1002/14651858.CD004907.pub3

[35] Wei, S., Wo, B.L., Xu, H., Luo, Z.C., Roy, C. and Fraser, W.D. (2009) Early Amniotomy and Early Oxytocin for Prevention of, or Therapy for, Delay in First Stage Spontaneous Labour Compared with Routine Care. Cochrane Database of Systematic Reviews, 4, Article NO.: CD006794. http://dx.doi.org/10.1002/14651858.CD006794.pub2

[36] Miller, S., Bergel, E.F., El Ayadi, A.M., Gibbons, L., Butrick, E.A., Magwali, T., Mkumba, G., Kaseba, C., Huong, N.M., Geissler, J.D. and Merialdi, M. (2013) Non-Pneumatic Anti-Shock Garment (NASG), a First-Aid Device to Decrease Maternal Mortality from Obstetric Hemorrhage: A Cluster Randomized Trial. PLoS One, 8, e76477. http://dx.doi.org/10.1371/journal.pone.0076477

[37] Georgiou, C. (2009) Balloon Tamponade in the Management of Postpartum Haemorrhage: A Review. BJOG: An International Journal of Obstetrics and Gynaecology, 116, 748-757. http://dx.doi.org/10.1111/j.1471-0528.2009.02113.x

[38] Lavender, T., Hart, A. and Smyth, R.M.D. (2013) Effect of Partogram Use on Outcomes for Women in Spontaneous Labour at Term. Cochrane Database of Systematic Reviews, 7, Article NO.: CD005461. http://dx.doi.org/10.1002/14651858.CD005461.pub4

[39] Duley, L., Gulmezoglu, A.M., Henderson-Smart, D.J. and Chou, D. (2010) Magnesium Sulphate and Other Anticonvulsants for Women with Pre-Eclampsia. Cochrane Database of Systematic Reviews, 11, Article NO.: CD000025. 
http://dx.doi.org/10.1002/14651858.CD000025.pub2

[40] Horan, K.M. (2009) Using the Human Patient Simulator to Foster Critical Thinking in Critical Situations. Nursing Education Perspectives, 30, 28-30. http://dx.doi.org/10.1043/1536-5026-030.001.0028

[41] Beaubien, J.M. and Baker, D.P. (2004) The Use of Simulation for Training Teamwork Skills in Health Care: How Low Can You Go? Quality and Safety in Health Care, 13, i51-i56. http://dx.doi.org/10.1136/qhc.13.suppl_1.i51

[42] Smith, S.J. (2009) High-Fidelity Simulation in Nursing Education: Factors Correlating with Nursing Student Satisfaction and Self-Confidence. Clinical Simulation in Nursing, 5, e150. http://dx.doi.org/10.1016/j.ecns.2009.04.073

[43] Marshall, M.N., Shekelle, P.G., Leatherman, S. and Brook, R.H. (2000) The Public Release of Performance Data: What Do We Expect to Gain? A Review of the Evidence. The Journal of the American Medical Association, 283, 1866-1874. http://dx.doi.org/10.1001/jama.283.14.1866

[44] Ronsmans, C., Graham, W.J. and Lancet Maternal Survival Series Steering Group (2006) Maternal Mortality: Who, When, Where, and Why. Lancet, 368, 1189-1200. http://dx.doi.org/10.1016/S0140-6736(06)69380-X

[45] Wholey, M.H., Stockdale, R. and Hung, T.K. (1970) A Percutaneous Balloon Catheter for the Immediate Control of Hemorrhage. Radiology, 95, 65-71. http://dx.doi.org/10.1148/95.1.65

[46] Mok, M., Heidemann, B., Dundas, K., Gillespie, I. and Clark, V. (2008) Interventional Radiology in Women with Suspected Placenta Accreta Undergoing Caesarean Section. International Journal of Obstetric Anesthesia, 17, 255-261. http://dx.doi.org/10.1016/j.ijoa.2007.11.010

[47] International Confederation of Midwives and International Federation of Gynecology and Obstetrics (2004) Joint Statement: Management of the Third Stage of Labour to Prevent Post-Partum Haemorrhage. Journal of Midwifery \& Women's Health, 49, 76-77. http://dx.doi.org/10.1016/j.jmwh.2003.11.005

[48] Blanks, A.M., Vatish, M., Allen, M.J., Ladds, G., de Wit, N.C., Slater, D.M. and Thornton, S. (2003) Paracrine Oxytocin and Estradiol Demonstrate a Spatial Increase in Human Intrauterine Tissues with Labor. The Journal of Clinical Endocrinology \& Metabolism, 88, 3392-3400. http://dx.doi.org/10.1210/jc.2002-021212

[49] O’Driscoll, K., Foley, M., and MacDonald, D. (1984) Active Management of Labor as an Alternative to Cesarean Section for Dystocia. Obstetrics \& Gynecology, 63, 485-490.

[50] Lester, F., Stenson, A., Meyer, C., Morris, J., Vargas, J. and Miller, S. (2011) Impact of the Non-pneumatic Antishock Garment on Pelvic Blood Flow in Healthy Postpartum Women. American Journal of Obstetrics \& Gynecology, 204, 4-9. http://dx.doi.org/10.1016/j.ajog.2010.12.054

[51] Lalonde, A., Daviss, B.A., Acosta, A. and Herschderfer, K. (2006) Postpartum Hemorrhage Today: ICM/FIGO Initiative 2004-2006. International Journal of Gynecology \& Obstetrics, 94, 243-253. http://dx.doi.org/10.1016/j.ijgo.2006.04.016

[52] RCOG and Royal College of Obstetricians and Gynaecologists (2011) Prevention and Management of Post-Partum Haemorrhage. Green-top Guidelines, 52, 1-24.

[53] Dabelea, V., Schultze, P.M. and McDuffie, R.S. (2007) Intrauterine Balloon Tamponade in the Management of Postpartum Hemorrhage. American Journal of Perinatology, 24, 359-364. http://dx.doi.org/10.1055/s-2007-984402

[54] Seror, J., Allouche, C. and Elhaik, S. (2005) Use of Sengstaken-Blakemore Tube in Massive Postpartum Hemorrhage: A Series of 17 Cases. Acta Obstetricia et Gynecologica Scandinavica, 84, 660-664. http://dx.doi.org/10.1111/j.0001-6349.2005.00713.x

[55] Condous, G.S., Arulkumaran, S., Symonds, I., Chapman, R., Sinha, A. and Razvi, K. (2003) The "tamponade test” in the Management of Massive Postpartum Hemorrhage. Obstetrics \& Gynecology, 101, 767-772. http://dx.doi.org/10.1016/S0029-7844(03)00046-2

[56] Akhter, S., Begum, M.R., Kabir, Z., Rashid, M., Laila, T.R. and Zabeen, F. (2003) Use of a Condom to Control Massive Postpartum Hemorrhage. MedGenMed, 5, 38.

[57] Harvey, S.A., Blandón, Y.C.W., McCaw-Binns, A., Sandino, I., Urbina, L., Rodríguez, C., Gómez, I., Ayabaca, P. and Djibrina, S. (2007) Are Skilled Birth Attendants Really Skilled? A Measurement Method, Some Disturbing Results and a Potential Way Forward. Bulletin of the World Health Organization, 85, 783-790. http://dx.doi.org/10.2471/BLT.06.038455

[58] WHO/MPS (2006) Pregnancy, Childbirth, Postpartum and Newborn Care: A Guide for Essential Practice. WHO/ UNFPA/UNICEF/The Worl Bank Group, 1-180.

[59] World Health Organization Maternal Health and Safe Motherhood Programme (1994) World Health Organization Partograph in Management of Labour. Lancet, 343, 1399-140. http://dx.doi.org/10.1016/S0140-6736(94)92528-3

[60] Kitchens, C.S. (2009) Thrombocytopenia and Thrombosis in Disseminated Intravascular Coagulation (DIC). American Society of Hematology Education Book, 2009, 240-246. http://dx.doi.org/10.1182/asheducation-2009.1.240 
[61] Hoveyda, F. and MacKenzie, I.Z. (2001) Secondary Postpartum Haemorrhage: Incidence, Morbidity and Current Management. An International Journal of Obstetrics \& Gynaecology, 108, 927-930. http://dx.doi.org/10.1016/S0306-5456(01)00230-3

[62] Alcazar, J.L. (1998) Transvaginal Ultrasonography Combined with Color Velocity Imaging and Pulsed Doppler to Detect Residual Trophoblastic Tissue. Ultrasound in Obstetrics \& Gynecology, 11, 54-58. http://dx.doi.org/10.1046/j.1469-0705.1998.11010054.x

[63] Maslovitz, S., Almog, B., Mimouni, G.S., Jaffa, A., Lessing, J.B. and Many, A. (2004) Accuracy of Diagnosis of Retained Products of Conception after Dilation and Evacuation. Journal of Ultrasound in Medicine, 23, 749-756, quiz 758-759.

[64] Sadan, O., Golan, A., Girtler, O., Lurie, S., Debby, A., Sagiv, R., Evron, S. and Glezerman, M. (2004) Role of Sonography in the Diagnosis of Retained Products of Conception. Journal of Ultrasound in Medicine, 23, 371-374.

[65] Kitzinger, S. (2000) Rediscovering birth. Little, Brown, and Company, Boston.

[66] Weissgerber, T.L., Wolfe, L.A. and Davies, G.A. (2004) The Role of Regular Physical Activity in Preeclampsia Prevention. Medicine \& Science in Sports \& Exercise, 36, 2024-2031. http://dx.doi.org/10.1249/01.MSS.0000147627.35139.DC

[67] Duley, L., Henderson-Smart, D.J. and Walker, G.J. (2009) Interventions for Treating Pre-Eclampsia and Its Consequences: Generic Protocol. Cochrane Database of Systematic Reviews, 2, Article No.: CD007756. http://dx.doi.org/10.1002/14651858.CD007756

[68] Garland, D. and Jones, K.C. (2000) Waterbirths: Supporting Practice with Clinical Audit. MIDIRS Midwifery Digest, 10, 333-336.

[69] Church, L.K. (1989) Water Birth: One Birthing Center's Observations. Journal of Nurse-Midwifery, 34, 165-170. http://dx.doi.org/10.1016/0091-2182(89)90076-1

[70] Ginesi, L. and Niescierowicz, R. (1998) Neuroendocrinology and Birth 1: Stress. British Journal of Midwifery, 6, 659663. http://dx.doi.org/10.12968/bjom.1998.6.10.659

[71] Hanson, U. and Persson, B. (1993) Outcome of Pregnancies Complicated by Type 1 Insulin-Dependent Diabetes in Sweden: Acute Pregnancy Complications, Neonatal Mortality and Morbidity. American Journal of Perinatology, 10, 330-333. http://dx.doi.org/10.1055/s-2007-994754

[72] Klein, H.U., Meltendorf, U.L.F., Reek, S., Smid, J.A.N., Kuss, S., Cygankiewicz, I., Jons, C., Szymkiewicz, S., Buhtz, F., Wollbrueck, A. and Zareba, W. (2010) Bridging a Temporary High Risk of Sudden Arrhythmic Death. Experience with the Wearable Cardioverter Defibrillator (WCD). PACE - Pacing and Clinical Electrophysiology, 33, 353-367. http://dx.doi.org/10.1111/j.1540-8159.2009.02590.x

[73] World Health Organization (2007) Iron Deficiency Anaemia, Assessment, Prevention, and Control: A Guide for Programme Managers.

[74] World Health Organization (1992), The Prevalence of Anaemia in Women: A Tabulation of Available Information (WHO/MCH/MSM/92). 2nd Edition. WHO, Maternal Health and Safe Motherhood Programme, Division of Family Health, Geneva.

[75] Mani, S. and Duffy, T.P. (1995) Anemia of Pregnancy. Clinics in Perinatology, 22, 593-607. 